\title{
Courts and the Environment: An Introduction
}

\section{Christina Voigt and Zen Makuch}

Across the globe, environmental protection is in need of strong governance arrangements: arrangements that comprise effective environmental laws and regulations, a functioning administration and an independent judiciary. Courts, often perceived as the third pillar of power alongside the legislative and executive functions of the State, have an important role to play in defending, upholding and (for judicial activists) creating an environmental rule of law. At the same time, many courts and their judges face significant challenges in doing so effectively. This volume looks at the possibilities and limitations that courts and judges encounter in protecting the environment.

Norms that seek to protect the environment, and the common values it represents, are widely dispersed. We find them in thousands of domestic laws and regulations; we find them in international and regional treaties and unwritten customary laws. Sometimes we do not find them at all.

In many jurisdictions, courts have important roles to play in this normative puzzle: they may be tasked to identify applicable norms as well as to interpret them, or they may be asked to give an authoritative statement of the content of norms. Courts may be conservative and protect the status quo. Yet they may also be dynamic creators of the law and contribute to the development of a rule of law that includes the protection of the environment.

We see this happening all over the world. Hundreds of cases at various domestic courts give us an empirical basis for understanding the possibilities and the limits that courts and judges face when confronted with claims that concern environmental protection and nature conservation.

The current environmental turn to the courts carries nuanced and varied developments, all of which can inform our learning experiences. For instance, we are witnessing a new trend in which citizens and environmental groups worldwide are bringing (or are about to bring) cases to their courts seeking legal remedies of a variety of kinds against companies and increas- 
ingly governments for inaction on climate change. In other words, we see an increased awareness of - and turn to - the role and power of 'Justitia'.

The ubiquity of this phenomenon provides excellent comparative opportunities for us to learn from one another everywhere as environmental law and environmental jurisprudence come of age together. This new opportunity is prescient because, as an agglomeration of nation states each sowing its own regulatory and jurisprudential paths, most of our societies must come to grips with the ominous environmental realities that are now just around the corner in real time. Among them are three examples:

- Climate change and projected warming of our planet by $4-5^{\circ} \mathrm{C}$ by 2100 in current business as usual scenarios with disastrous consequences for matters such as food security, buffeting and submersion of coastal areas (storms/sea level rise), acidification of our oceans (through $\mathrm{CO}_{2}$ ingress) and the calamities that attend more frequent and severe weather events across the globe. ${ }^{1}$

- Projected population growth by 2.5 billion people by 2050 , which will accelerate natural resource pressure and depletion as well as placing the carrying capacities of the ecosystem under severe stress. ${ }^{2}$

- Species extinction rates at 1000-10,000 times the natural background rate of one to five species per year. ${ }^{3}$

Against the backdrop of these developments, a range of courts and tribunals are engaged in the exercise of interpreting and evolving the

1 Holly Riebeek, 'The Rising Cost of Natural Disasters' (NASA, Earth Observatory, 28 March 2005) https://earthobservatory.nasa.gov/Features/RisingCo st/rising_cost.php accessed 19 December 2017; Intergovernmental Panel on Climate Change, The Regional Impacts of Climate Change: An Assessment of Vulnerability (SPECIAL REPORT by R. Watson, M. Zinyowera and R. Moss, 1997); National Oceanographic and Atmospheric Administration (NOAA), 'Ocean Acidification: Saturation State Dataset' (NOAA, 2017) https://sos.noaa.gov/datasets/ocean-acidifi cation-saturation-state accessed 15 December 2017; Climate Action Tracker, 'Effect of Current Pledges and Policies on Global Temperature' (Global Temperatures Climate Action Tracker, 2018) http://climateactiontracker.org/global.html accessed 4 January 2018.

2 Alex de Sherbinin, David Carr, Susan Cassels and Leiwen Jiang, 'Population and Environment' [2007] Annual Review of Environment and Resources 32:345; United Nations, Department of Economic and Social Affairs, Population Division, World Urbanization Prospects: The 2014 Revision, Highlights (ST/ESA/ SER.A/352, 2014).

3 Eric Chivian and Aaron Bernstein (eds.), Sustaining Life: How Human Health Depends on Biodiversity (Center for Health and the Global Environment, OUP 2008). 
environmental rule of law: these range from specialist environmental courts, to constitutional, administrative, criminal or civil suit courts in various domestic jurisdictions. The question that arises is: what does this dispersed, pluricentral picture tell us? Here the stresses and strains of multi-stakeholder interests veer between one-size-fits-all and highly individuated national solutions to the vexing questions of environmental law. How well are courts and judges situated to protect the environment? We see answers that are as varied as the participants and their interests in jurisprudential deliberations and debate. Are they solely a forum of last resort when regulators fail? What we are learning here is that there are a variety of corresponding jurisprudential answers and that courts span the gamut of judicial styles from passive interpretation of fixed precedents to, at times, unexpected judicial activism, if not quasilegislative action.

Courts are independent and can sometimes, more so than policymakers, ensure the strength, quality and longevity of environmental protection. Or are they independent? Are they a necessary corrective to sometimes short-lived or missing political attention to environmental protection? Can they be? Should they be? Which challenges do courts face? And which challenges do potential litigants face in bringing a case to a court or defending against it? What does experience tell us? Where do we stand today and what role can and should we expect from environmental adjudication in the future? As the answers to questions in this paragraph broadly reflect the individuality, serendipity and multivariate nature of our adjudicators as both professionals and people in their own right, we must reconcile ourselves with the preliminary conclusion that environmental law remains rather more synonymous with art than the environmental science upon which it can often be based. For those that are in search for solutions to certain deepening environmental crises by way of enlightened governance or normative design, that can be a source of frustration, if not despair.

However, our twin capacities for reasoning and persistence make us well suited as environmental legislators, scholars, practitioners and stakeholder participants to carry forward our mission of maturing this youthful field. If we can follow this path with accelerated intent in view of the existential questions that our consumptive existence has posed, then we have at least a chance to maintain, if not enhance, our fragile civilization in harmony with the planet.

With this important mission in mind, we invite the reader to participate in learning from one another in the richness and diversity of environmental problem solving that regulators, adjudicators and scholars have produced in this collective work. Perhaps applying the lessons of success and failure 
whether they come from next door or the other side of the earth will enrich the evolution of environmental protection and nature conservation in diverse corners of the planet. After all, to extend the metaphor of environmental law as art, it is a hallmark of humanity that we look to art as a form of inspiration and a reminder of our better natures. In this regard, studying the body and form of environmental jurisprudence reveals some of the following emerging contours:

- a willingness to look to and learn from other jurisdictions in shaping judicial reasoning and results;

- the increasingly thoughtful interpretation and elaboration of environmental norms and principles as they enter common parlance among national jurisdictions (e.g., the polluter pays and precautionary principles);

- growing national acceptance of the proceduralization of environmental rights of access to information, decision-making processes and their judicial oversight/interpretations;

- the recognition that vis-à-vis the private sector, governmental bodies share a co-equal if not pre-eminent role and legal responsibility for our planetary fate in respect of ecosystem protection;

- that those same governmental bodies will face a range of legal challenges and corresponding remedies for any deficit by way of an act or omission to act on our most pressing environmental challenges;

- that regulatory failure on, perhaps our most important environmental crisis (i.e. climate change) will have both legal and political consequences;

- the creative interplay of non-environmental law sources and remedies with exemplar contributions from such areas as human rights law, land law, constitutional law and the common law;

- multi-stakeholder cooperation in legal action through coalitionbuilding variously from among individuals, NGOs, academia, unions, investors, progressive government bodies and companies; and,

- the mobilization of collective legal actions (collective suits, class actions, etc.) measured in the hundreds and occasionally thousands of individuals seeking legal remedies for serious environmental harms, or the prevention thereof, through national courts.

Given the normative, governance and existential imperatives of environmental law, the timing for this volume could not be more suitable. With the establishment and consolidation of legislative frameworks for the 
environment, we are at a point where this now established discipline can be used as a tool for testing the individual and collective resolve to protect the environment through legal action and adjudication. Noting that environmental cases brought before either specialist environmental courts and tribunals or general courts are measured in their hundreds, providing a volume that describes their varied experiences offers the opportunity for reciprocal learning across and within jurisdictions.

Against the backdrop of these trends, this volume looks at the possibilities and challenges of courts and of judges in adjudicating environmental cases or cases with environmental aspects. It does so by bringing together experiences and expertise from 17 different countries. The experiences cover a large variety of domestic courts, ranging from the National Green Tribunal in India, the Australian Land and Environment Court in New South Wales, the Environment Court of New Zealand, the District Court of The Hague in the Netherlands, Western, Central and Eastern European Courts, Indonesia's and Brazil's Constitutional Courts and the Supreme People's Court in China - just to mention a few.

It is structured in four parts as follows:

I Conceptualizing the Role of Courts in Protecting the Environment;

II Taking the Lead: The Court as Trailblazer for Environmental Protection;

III Access to Justice for the Environment; and

IV Courts in Action.

We have produced this structure because academic research of this nature should begin by offering conceptual overviews of the role and place of courts in establishing, maintaining and enhancing environmental justice (see Part I). We move from the conceptual to the empirical, in the first instance, by calling attention to the need to promote a progressive role for courts in facilitating the environmental needs of civil society. This is the essence of Part II, 'Taking the Lead'. In Part III, we span some of the continents for a more comparative understanding of how selected procedural innovations in environmental law can be brought to bear upon advancing 'access to environmental justice'. Finally, in Part IV, we look specifically at the courts themselves 'in action' for their actual contribution to the corpus of respective national environmental laws.

Further to this structure, in Chapter 1, Robinson takes the reader through a historical, scholarly journey asking us whether justice has a home. The journey traverses a path from the Magna Carta (1215) to the contemporary world in which the United Nations Environment Programme Governing Council declared a new kind of 'environmental 
justice' in its Decision on advancing justice, governance and law for environmental sustainability (27/9). ${ }^{4}$

In Chapter 2, Preston, Martin and Kennedy explore environment and governance principles using a transaction systems approach. They do this in order to identify factors that impact the effectiveness of the court in implementing the precautionary principle as an example. Their specific focus is on the implementation of the precautionary principle in the Australian state of New South Wales, home to a specialist Land and Environment Court.

In Chapter 3, Daya-Winterbottom examines the reality and remaining potential of human, national/international environmental, property and cultural rights-based phenomena. This rights-based typology yields insights as to the inherently flexible nature of this paradigm for advancing the environmental well-being of our planet. Noting its anthropocentric limitations, the author nevertheless concludes that where rights-based approaches are integrated within well-designed environmental regulation featuring evidence-based legal and technical standards in a well-conceived implementation framework, they have much to contribute to our collective environmental mission.

Moving on to the second part of the book which addresses the leadership role of courts in promoting environmental protection, in Chapter 4, Dzah explores the means by which Ghana's courts can develop an environmental rule of law as a critical feature of environmental justice. He does this by reference to an illustration of the requisite components of environmental governance and the state of environmental adjudication to date with some comparative references to Kenya. He concludes by calling for a specialist environment court.

In Chapter 5, Ferreira, Serraglio and Mendes call our attention to the legal treatment of the Amazon and Cerrado biomes of Brazil. After establishing that the legislative and policy efforts to maintain and enhance these biomes have been insufficient to date, the authors examine judicial pronouncements against the backdrop of current and future climate change challenges for relevant ecosystems.

In their chapter (6) on the treatment of environment and development aims in the Indian courts, Jolly and Makuch have found that the judicial process has played an activist role in evolving substantive and procedural rules to balance the protection of environment and development. They then proceed to analyse how the adoption and interpretation of

4 United Nations Environment Programme Governing Council, Decision on advancing justice, governance and law for environmental sustainability $(27 / 9,2013)$. 
sustainable development features by the Indian judiciary has assisted in balancing the needs of environment protection and development.

Under our book's Part 3 banner of 'access to justice for the environment', Ho Tu Nam's chapter (7) focuses upon the role of the African Commission on Human and Peoples' Rights in facilitating civil society efforts to bring environmental infringements to the attention of the Commission. This is cast against the broader backdrop of the role of civil society and institutions in pursuing environmental justice with a series of recommendations for reform.

In Chapter 8, Lamprea and Páez provide an empirical assessment of the jurisprudence on environmental popular actions in Colombia with comparisons to other parts of Latin America. They present the results of their research and discuss their implications against the backdrop of the Congressional decision (2010) to remove economic incentives for these types of legal action.

In Chapter 9, Pepper and Butterly analyse the role of courts in the protection of Indigenous cultural heritage in Australia. Their chapter provides both a judicial and academic perspective on these issues, to draw what otherwise may be discrete ideas together and to suggest practical examples of legal reform (both inside and beyond the courtroom).

Moving on to a comparative legal analysis of China and the USA, in Chapter 10, Zhang demonstrates how public interest litigation has been introduced in China - supported by new environmental laws - as an approach to broaden and strengthen access to environmental justice. The origin of the public interest litigation in the United States and its continuous improvement are also introduced and discussed with the Clean Air Act and its amendments serving as specific examples.

Chapter 11, by Chornous and Kichigan, addresses implementation of the access to information, public participation and access to justice pillars of the Aarhus Convention including by reference to the states of Kazakhstan, Russia and Ukraine. After identifying implementation challenges related to the phenomena of economic crisis, corruption, environmental (un)consciousness and judicial inconsistency, the authors provide instructive implementation recommendations through rightsbased solutions.

Moving on the last part of the book on 'Courts in Action', in Chapter 12 León Moreta and Liu elucidate the challenge of making transnational firms liable for environmental impacts due to weak judicial structures and the lack of effective mechanisms to redress in developing countries. The chapter then demonstrates how the alternative fora that such firms have access to in order to uphold their corporate rights effectively prevent the effective enforcement of environmental decisions at national and 
international levels. A particular focal point is the legal conflicts between the Texaco and Chevron oil firms and Lago Agrio complainants.

In Chapter 13, Dewi and Jayadi connect Indonesian environmental protection issues to corporate responsibility with a summary of relevant Indonesian and nationally ratified international law including with respect to human rights. They conclude by discussing the relative absence of certain key substantive legal requirements and its relation to the Indonesian government's efforts to address the right to a clean environment through corporate social responsibility activities.

In Chapter 14, Spijkers analyses the Urgenda case, a judicial decision requiring that the Dutch Government achieve 25 per cent reductions of greenhouse gas emissions by $2020 .^{5}$ The chapter explores whether the Urgenda case can be seen as a successful example of public interest litigation for the protection of the environment. At issue is the relationship between the executive, legislative and judicial branches and the level of indeterminacy associated with a ruling using the amorphous concept of the 'duty of care'.

Also with specific reference to litigation, in Chapter 15, Hodas provides the reader with a case study of how administrative and judicial adjudication placed the United States on a path of sustainable development. This adjudication provided said result even though courts did not view their role as one of promoting and creating sustainable development law or policy generally, or climate change policy in particular. The lessons from this litigation saga have general application because the jurisprudence is derived from traditional administrative law doctrines and procedures.

In the penultimate chapter (16), Guidone and Jonas shed light on specific national environmental court and tribunal experiences, with a focus on the Asia-Pacific region. The chapter identifies advantages and disadvantages in developing specialized environmental courts and tribunals and lessons learned over the years in such places as Kenya, Canada, Sweden, Australia, China, India and the Philippines. The research conducted, as well as expert consensus, indicates that environmental courts and tribunals are both relevant and useful in achieving environmental governance goals.

In Chapter 17, Bengtsson offers a concise overview of how specialized Swedish civil and administrative courts evolved and how they are organized. He also explains the available choices between systems and

5 District Court of The Hague, Judgment of 24 June 2015 in the case between the Urgenda Foundation and the State of the Netherlands (Ministry of Infrastructure and the Environment). English translation available at: http://deeplink.rechtspraak. nl/uitspraak?id=ECLI:NL:RBDHA:2015:7196. 
the different procedures applied depending on the kind of case at hand. Finally, he offers lessons of his experience from working as a judge in a land and environment court and how that work has been affected during the last years inter alia due to a shift in how to apply different sources of law.

In conclusion, by analysing and comparing litigation and related legislative practices and experiences from different jurisdictions, this volume attempts to enhance mutual learning and understanding. It is motivated by the hope that the different legal perspectives and traditions represented by judges and academics from many different parts of the world, different ages and gender are brought together by safeguarding the values that unite us: the value of protecting and conserving the environment, the value of a dignified and environmentally sustainable life for all within an economy defined by safe ecological boundaries.

Last, but not least, we would like to express our sincere gratitude to all who supported this project. Our thanks goes to all the authors who dedicated their time, efforts and energy to writing the content of this book and who willingly and enthusiastically share their experiences, insights and reflections with the readers.

Moreover, the project would have been impossible without the IUCN Academy of Environmental Law. The book also benefitted greatly from the generous support provided by Pluricourts, the centre of excellence at the University of Oslo, for the study of the legitimate roles of the judiciary in the global order. Our thanks also goes to the Bren School of Environmental Science and Management, University of California Santa Barbara, and the William S. Richardson School of Law, University of Hawaíi at Mānoa, Honolulu, for providing office space during the editing work of this volume.

Many individuals helped shape this work, most notably among them Louis J. Kotzé, Research Professor, North-West University, South Africa, who provided valuable input, as well as Ben Booth, Senior Commissioning Editor at Edward Elgar Publishing, who entrusted us with carrying out the editorial work.

We are grateful for having had the privilege of working together with so many inspiring minds in bringing this project to fruition. It has been a truly humbling and rewarding experience. 